IZA DP No. 9724

Integrated Macroeconomic Production Function for Open Economies:

A New Schumpeterian Solow Model for Globalization

Paul J.J. Welfens

February 2016 


\title{
Integrated Macroeconomic Production Function for Open Economies: A New Schumpeterian Solow Model for Globalization
}

\author{
Paul J.J. Welfens \\ EIIW and Schumpeter School, University of Wuppertal, \\ Sciences Po, IZA and AICGS/Johns Hopkins University
}

\author{
Discussion Paper No. 9724 \\ February 2016
}

\author{
IZA \\ P.O. Box 7240 \\ 53072 Bonn \\ Germany \\ Phone: +49-228-3894-0 \\ Fax: +49-228-3894-180 \\ E-mail: iza@iza.org
}

\begin{abstract}
Any opinions expressed here are those of the author(s) and not those of IZA. Research published in this series may include views on policy, but the institute itself takes no institutional policy positions. The IZA research network is committed to the IZA Guiding Principles of Research Integrity.

The Institute for the Study of Labor (IZA) in Bonn is a local and virtual international research center and a place of communication between science, politics and business. IZA is an independent nonprofit organization supported by Deutsche Post Foundation. The center is associated with the University of Bonn and offers a stimulating research environment through its international network, workshops and conferences, data service, project support, research visits and doctoral program. IZA engages in (i) original and internationally competitive research in all fields of labor economics, (ii) development of policy concepts, and (iii) dissemination of research results and concepts to the interested public.
\end{abstract}

IZA Discussion Papers often represent preliminary work and are circulated to encourage discussion. Citation of such a paper should account for its provisional character. A revised version may be available directly from the author. 


\section{ABSTRACT}

\section{Integrated Macroeconomic Production Function for Open Economies: A New Schumpeterian Solow Model for Globalization*}

The macroeconomic production function is a traditional key element of modern macroeconomics, as is the more recent knowledge production function which explains knowledge/patents by certain input factors such as research, foreign direct investment or international technology spillovers. This study is a major contribution to innovation, trade, FDI and growth analysis, namely in the form of a combination of an empirically relevant knowledge production function for open economies - with both trade and inward FDI as well as outward foreign direct investment plus research input - with a macro production function. Plugging the open economy knowledge production function into a standard macroeconomic production function yields important new insights for many fields: The estimation of the production potential in an open economy, growth decomposition analysis in the context of economic globalization and the demand for labor as well as long run international output interdependency of big countries; and this includes a view at the asymmetric case of a simple two country world in which one country is at full employment while the other is facing underutilized capacities. Finally, there are crucial implications for the analysis of broad regional integration schemes such as TTIP or TPP and a more realistic and comprehensive empirical analysis.

JEL Classification: E23, F02, F62, 011, 032

Keywords: potential output, innovation, knowledge production function, macroeconomics, globalization

Corresponding author:

Paul J.J. Welfens

European Institute for International Economic Relations

University of Wuppertal

Rainer-Gruenter-Straße 21

D-42119 Wuppertal

Germany

E-mail: welfens@eiiw.uni-wuppertal.de

\footnotetext{
* I gratefully acknowledge discussions with and research assistance by Jens Perret and Vladimir Udalov as well as editorial assistance by David Hanrahan. Particular thanks go to Andre Jungmittag, Frankfurt School of Applied Sciences, for stimulating discussion - the reader is also referred to the companion empirical paper EIIW No. 212. The usual disclaimer applies. This paper is dedicated to the late Edward Graham, Petersen Institute for International Economics - he has conducted crucial research on foreign direct investment in the world economy.
} 


\section{Integrated Macroeconomic Production Function for Open Economies: A New Schumpeterian Solow Model for Globalization}

\section{Table of Contents}

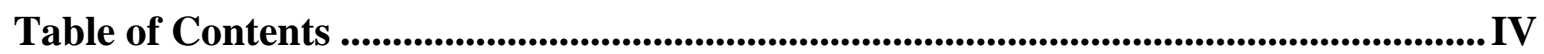

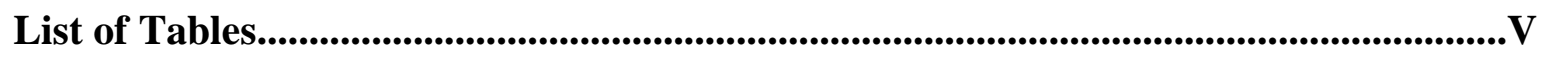

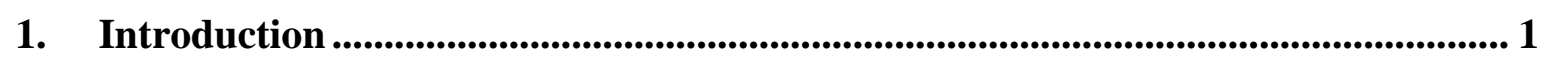

2. Knowledge Production Function and Macroeconomic Production Function ....... 4

2.1 Theoretical Aspects of the Knowledge Production Function................................. 4

3. The Schumpeterian Macroeconomic Production Function ................................... 8

3.1 Output Elasticity with Respect to Foreign Knowledge .................................... 11

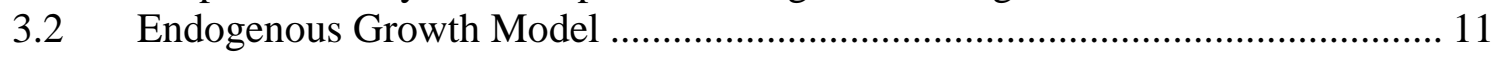

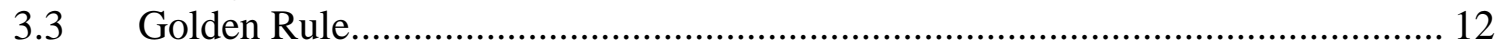

3.4 Labor Market Demand and other Macro Aspects …........................................ 13

3.5 Hybrid Medium-Term Macro Model ..................................................................... 14

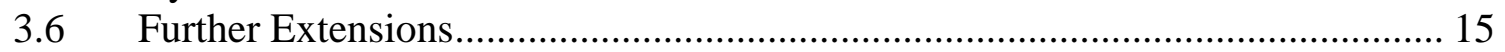

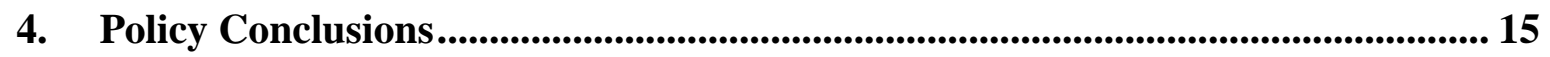

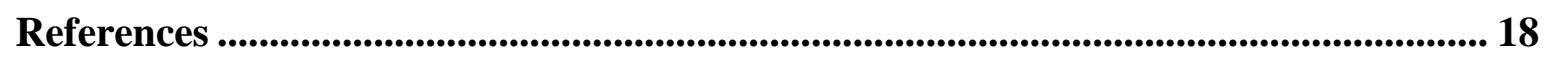

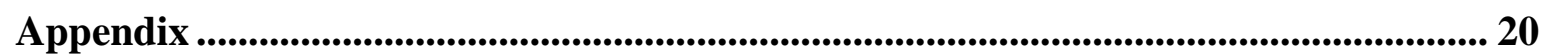

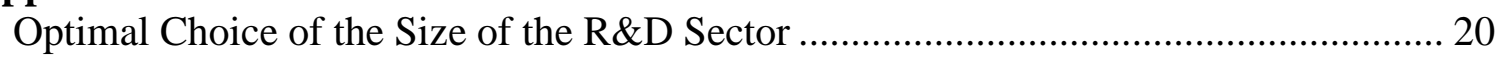

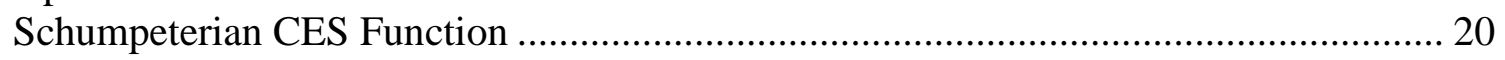




\section{List of Tables}

Table 1: Tab. 1: Knowledge Production Function: patent applications at the European Patent Office explained by researchers (full time equivalent), per capita GDP (PPP, constant dollars), inward FDI-GDP ratio: panel data analysis for $20 \mathrm{EU}$ countries, 2002-2012; all variables in logs....................................................................2 



\section{Introduction}

The macroeconomic production function is a key element of modern macroeconomics, as is the more recent knowledge production function which explains knowledge/patents by certain input factors such as research or international technology spillovers. This contribution gives an innovative consistent combination of the knowledge production function for open economies with both trade and inward as well as outward foreign direct investment. Macroeconomic production functions such as the Cobb-Douglas function $\mathrm{Y}=\mathrm{K}^{\mathrm{\beta}}(\mathrm{AL})^{1-\beta}$ (where output is $\mathrm{Y}, \mathrm{K}$ is capital, $\mathrm{L}$ is labor and $\mathrm{A}$ is knowledge) and the CES production function $\mathrm{Y}=\lambda\left[(1-\Omega)(\mathrm{AL})^{-\mathrm{v}^{\prime \prime}}+\Omega \mathrm{K}^{-\mathrm{v}^{\prime \prime}}\right]^{-1 / \mathrm{v}^{\prime \prime}}$ are useful workhorses of modern Economics. For the economic analysis of a full employment economy and neoclassical economic growth models these functions are a natural element (WELFENS, 2011).

While technological progress in a neoclassical growth model falls like manna from heaven, a better approach is endogenous growth modeling - namely with knowledge explained in turn by a knowledge production function which is a familiar concept in Innovation Economics (GRILICHES, 1979; AGHION/HOWITT, 1998). The knowledge production function is a broad concept that includes key questions such as understanding the link between innovation dynamics - patent stocks and flows as well as entrepreneurial variables - and total factor productivity growth as well as the spatial aspects of R\&D activities and regional innovation plus inter-regional innovation spillovers (e.g. PERRET, 2013). The focus of analysis is at first sight rather traditional, namely to look at a macroeconomic knowledge production function which has received some attention in the earlier literature (e.g. MACHLUP, 1979) and which also has complementary research strands with a focus on sectoral knowledge production functions (e.g. for Germany: BÖNTE, 2001). Open economy aspects thus far were mainly considered in the context of intermediate technology-intensive input imports and related questions relevant for total factor productivity growth (e.g. COE/HELPMAN, 1995); with respect to the empirical relevance of this concept KELLER (2000) has raised crucial objections. JUNGMITTAG (2004) has emphasized the role of trade and high-technology specialization for economic catching-up in an empirical EU context. The globalization of innovation - and hence the role of multinational companies - has received increasing attention since the beginning of the $21^{\text {st }}$ century (e.g. NARULA/ZANFEI, 2005; UNCTAD, 2005, VEUGELERS, 2005), however, it has not been much considered in international macroeconomics and regional integration analysis although deep integration projects, such as the EU-US project TTIP (Transatlantic Trade and Investment Partnership) or the project TPP (Trans-Pacific Partnership) of the US with countries around the Pacific Basin, suggest to consider the interaction of trade, FDI, innovation and output dynamics simultaneously - and not to focus solely on trade dynamics. Given recent studies which look in a micro perspective at the link between FDI and trade or innovation and exports (e.g. DUNNING/LUNDAN, 2008; LACHENMAIER/WÖSSMANN, 2006), one may argue that there is broad empirical evidence for some links at the micro level or the sectoral level, but standard international macroeconomics has not integrated FDI, innovation and trade in a systematic way.

The special feature considered here is the simultaneous open economy focus on trade and FDI for knowledge production - and the link of knowledge dynamics with macroeconomic output dynamics. The following approach is a major analytical innovation for the case of 
an open economy with imports and exports of goods and services and both inward foreign direct investment and outward FDI. Applying this concept to 20 EU countries has resulted in clear empirical evidence supporting this approach (JUNGMITTAG/WELFENS, 2016) as the regression analysis shows.

Table 1: Tab. 1: Knowledge Production Function: patent applications at the European Patent Office explained by researchers (full time equivalent), per capita GDP (PPP, constant dollars), inward FDI-GDP ratio: panel data analysis for 20 EU countries, 2002-2012; all variables in logs

Dependent Variable: LOG(PAT?)

Method: Pooled Least Squares

Date: 01/14/16 Time: 17:10

Sample: 20022012

Included observations: 11

Cross-sections included: 20

Total pool (unbalanced) observations: 205

\begin{tabular}{crlrr}
\hline \hline Variable & Coefficient & Std. Error & t-Statistic & Prob. \\
\hline \hline C & -16.75261 & 1.936751 & -8.649851 & 0.0000 \\
LOG(RDPERS?) & 0.354843 & 0.091091 & 3.895492 & 0.0001 \\
LOG(PGDPDOLLAR?) & 1.819009 & 0.194151 & 9.369062 & 0.0000 \\
LOG(FDISTOCKQ?) & 0.164400 & 0.074407 & 2.209453 & 0.0284 \\
Fixed Effects (Cross) & & & \\
_AT--C & 0.522542 & & \\
-BE--C & 0.384865 & & \\
-CZ--C & -0.911734 & & \\
-DK--C & 0.118808 & & \\
-FI-C & 0.432950 & & \\
-FR--C & 1.701492 & & \\
-DE--C & 2.471143 & & \\
-GR--C & -1.365439 & & \\
-HU--C & -0.343212 & & \\
-IE-C & -1.054935 & & \\
-IT-C & 1.424113 & & \\
-LU--C & -2.833316 & & \\
_NL--C & 0.804435 & & \\
-PL--C & -0.270742 & & \\
-PT--C & -1.450550 & & \\
-SK--C & -1.585013 & & \\
_SI-C & -0.856756 & & \\
-ES--C & 0.238784 & & \\
_SE--C & 0.739902 & & \\
-UK--C & 1.326632 & & \\
\hline \hline
\end{tabular}

Source: JUNGMITTAG/WELFENS (2016), Tab. 1, forthcoming

The approach presented here suggests a consistent integration of the knowledge production function in the macroeconomic production function and it seems obvious that this two- 
pronged analytical perspective on knowledge and output is useful for a world economy characterized by globalzation and innovation. In the US, Europe and China/ASEAN, trade and foreign direct investment have played an increasing role both in the form of inward FDI and as outward FDI (KRUGMAN/GRAHAM, 1995; UNCTAD, 2014; ADB, 2015; WORLD BANK, 2016).

The knowledge production function suggested here is straightforward and its implication for a Cobb-Douglas production function likewise - it is very interesting and allows a much better understanding of some key economic questions than previously. Plugging the knowledge production function - that is empirically robust - into a standard macroeconomic production function yields important new insights for many fields: The estimation of the production potential in an open economy, growth decomposition analysis in the context of economic globalization and the demand for labor, as well as long run international output interdependency of big countries - and this includes a view at the asymmetric case of a simple two country world in which one country is at full employment while the other is facing underutilized capacities. Estimation of the production potential is important in many ways, not least for the analysis of structural budget deficits and capacity utilization. Finally, the debate about output multipliers can be stated within the new framework in a different way than was the case in the traditional debate. Since economic globalization has continued for decades - with trade intensities and cumulated FDI inflows and FDI outflows (relative to GDP) increasing - it is important to get a better understanding of the supply-side dynamics in open economies.

There is clear evidence that over time the export-GDP ratio and the import-GDP ratio in OECD countries as well as in NICs are growing. A similar observation holds for the ratio of inward FDI stocks in OECD countries, since about 1985, and also for outward FDI stocks of OECD countries (and for some newly industrialized countries this also holds).

The following section states at first a knowledge production function which can be considered as robust with respect to OECD countries; here the intensity of exports (x:= $\mathrm{X} / \mathrm{Y}$ where $\mathrm{X}$ is export volume) and the intensity of imports $(\mathrm{j}:=\mathrm{J} / \mathrm{Y}$; where $\mathrm{J}$ stands for the real import volume) as well as the share of cumulated inward FDI in the total capital stock $\left(\alpha^{*}\right)$ and the share $(\alpha)$ outward cumulated FDI in the foreign capital stock as well as the share of researchers in the total labor force is crucial; plus some other variables. The next step is to plug the knowledge production function into the production function and to take a closer look at some key implications, including the marginal product of labor and long run labor demand, respectively. There also are several key implications for the supply side and growth dynamics in open economies - and also selected policy implications will have to be considered.

The Schumpeterian Macro Production Function obtained from plugging the knowledge production function for an open economy brings many new insights; these include:

- a new understanding of the rather complex input factors that determine output in an open economy with inward and outward FDI, trade and research activities; this includes the complex elasticity of output with respect to foreign knowledge

- a new view on the long term interdependency of output in a two country approach

- an empirically valid endogenous growth model (with analytical solutions restricted to certain parameter conditions) 
- a new solution for the golden rule

- a new view on the role of domestic and foreign real money balances for domestic full employment equilibrium output

- a clear understanding that in an economy with trade and two-way FDI the long run foreign output growth rate will be one of the determinants of long run steady state economic growth - along with specific parameters from the knowledge production function

- a better - more realistic - basis for supply-side policy actions in open economies.

- One also can easily understand that this includes opportunities for international policy cooperation.

\section{Knowledge Production Function and Macroeconomic Production Function}

Since the Industrial Revolution, the creation of new knowledge has been a key driver of economic growth. Patent protection has been the institutional innovation that has stimulated innovation in the industrial sector since the 1830s (with the temporary notable exceptions of Switzerland and Netherlands which had no patent protection for some time as an ultra-liberal position taken by society and government suggested that having no intellectual property rights would be the best way to stimulate new knowledge). The modern economy in which services are dominating in terms of value-added and employment still has a crucial industrial core and patent applications continue to be a valuable indicator for innovation dynamics - although part of innovation dynamics is covered by copyrights and, in certain fields, through the very speed of innovation waves as is the case, for example, in part of the digital economy. As regards international trade in new knowledge, there is broad consensus amongst economists that technological information/knowledge markets are very imperfect since revealing part of knowledge for free is required in order for potential buyers to assess the economic value of the respective innovation. At the same time, there is the problem of asymmetric information and opportunistic behavior which implies rather low opportunities for patent trading; most international exchange of new knowledge is in the form of intra-company licenses in multinational companies or cross-licensing among MNCs.

\subsection{Theoretical Aspects of the Knowledge Production Function}

In an open economy it is straightforward to assume that trade intensity - proxied through $\mathrm{X} / \mathrm{Y}$ or $\mathrm{X} / \mathrm{L}$ and $\mathrm{J} / \mathrm{Y}$ or $\mathrm{J} / \mathrm{L}$, respectively - will contribute to knowledge $\mathrm{A}$ ( $\mathrm{X}$ is export volume, $\mathrm{J}$ is import volume; $\alpha$ is the share of country 1 investors' ownership of the foreign capital stock $\mathrm{K}^{*} ; \alpha^{*}$ is the share of foreign ownership of the capital stock $\mathrm{K}$ of country 1, ); on the import side, intermediate technology-intensive products in particular should contribute to raising knowledge in line with the arguments of COE/HELPMAN (1995) and a high export intensity should also put pressure on the aggregate of firms to raise knowledge, namely in line with MELITZ (2003) whose argument is that in a world with 
heterogeneous firms, opening up for trade will allow the most productive firms to expand through exports while the weakest firms, in terms of productivity and knowledge, respectively, will leave the market. Moreover, the size of the R\&D sector ( $z^{\text {" }}$ is the share of output devoted to R\&D) and the share of cumulated inward FDI relative to $K\left(\alpha^{*}\right)$ - or to $\mathrm{Y}$ - plus the sourcing of foreign technologies abroad through relative outward FDI stocks (proxied by $\alpha \mathrm{K}^{*} / \mathrm{Y}^{*}$ or $\alpha \mathrm{K}^{*} / \mathrm{K}$ ) should contribute to knowledge. Inward FDI stock is naturally associated with intra-company international technology transfer from the headquarter to subsidiaries, a high outward FDI stock in technologically leading OECD countries should allow to tap foreign technological progress through asset-seeking FDI and in this context not least through regional innovation spillovers abroad as well as through R\&D projects conducted abroad. Hence, with positive parameters $H, V^{\prime}, V^{\text {“ }}, \mathrm{V}$ and $\mathrm{V}^{*}$, one can state the knowledge production function as follows:

$\left(1^{\prime \prime}\right) \mathrm{A}=(\mathrm{X} / \mathrm{L})^{\mathrm{H}}(\mathrm{J} / \mathrm{L})^{\mathrm{V}}\left(\mathrm{z}^{\prime \prime} \mathrm{Y}\right)^{\mathrm{V}^{\prime \prime}}\left(\alpha^{*} \mathrm{~K} / \mathrm{Y}\right)^{\mathrm{V}}\left(\alpha \mathrm{K}^{*} / \mathrm{Y}^{*}\right)^{\mathrm{V} *}$

As regards the international technology transfer from abroad one might consider alternatively to $\left(\alpha \mathrm{K}^{*} / \mathrm{Y}^{*}\right)$ the variable $\alpha \mathrm{K}^{*} / \mathrm{Y}$ since the asset-seeking (knowledge-seeking) cumulated outward FDI relative to the GDP of the source country of FDI could be the relevant indicator - empirical analysis has to clarify this point (note that $\alpha \mathrm{K}^{* / \mathrm{Y}}$ can be rewritten as $\left(\alpha \mathrm{K}^{*} / \mathrm{Y}^{*}\right)\left(\mathrm{Y}^{*} / \mathrm{Y}\right)$ so that the subsequently derived integrated Schumpeterian macroeconomic production function - with the knowledge production function integrated into the macro production function - would have to be slightly reformulated). The equation stated to some extent seems to be in line with the skeptical view of JONES (1995) who has raised some doubts about the rather optimistic view of ROMER (1990) who suggests that the number of researchers determines the growth rate of knowledge; JONES uses total factor productivity (TFP) as a measure of knowledge. Interestingly, the model presented here suggests that the foreign rate of technological progress as well as the domestic level of knowledge contribute to output expansion: A determines the level of the output growth path, but the model with an exogenous foreign growth rate of knowledge (a*) implies that the trend growth rate of GDP in country 1 is affected by a*. ABDIH/JOUTZ (2005) using patents to proxy the stock of knowledge - have argued with respect to the USA that a simple knowledge production function could be stated as $d A / d t=a^{\prime} L^{, a "} A^{c "}$ ( $t$ is time, $L^{\prime}$ is the number of researchers, a', a" and c" are positive parameters) and the authors estimate a long run relationship: that doubling the stock of knowledge (patent stock) will raise TFP by only 10 percent in the long run.

The approach developed here follows the above equation (1") and some standard equations from macroeconomics:

Assuming $\mathrm{X}=\mathrm{xY} \mathrm{Y}^{*}$ and $\mathrm{J}=\mathrm{j} \mathrm{Y}$ one may write $(0<\mathrm{x}<1 ; 0<\mathrm{j}<1)$ :

(2”) $\mathrm{A}=\left(\mathrm{xy} \mathrm{Y}^{*} / \mathrm{Y}\right)^{\mathrm{H}}(\mathrm{jy})^{\mathrm{V}^{\prime}}\left(\mathrm{z}^{\prime \prime} \mathrm{Y}\right)^{\mathrm{V}^{\prime \prime}}\left(\alpha^{*} \mathrm{~K} / \mathrm{Y}\right)^{\mathrm{V}}\left(\alpha \mathrm{K}^{*} / \mathrm{Y}^{*}\right)^{\mathrm{V}^{*}}$ 
The ratio of $\mathrm{R} \& \mathrm{D}$ workers $\mathrm{L}$ ' to total employment $\mathrm{L}$ is $\mathrm{L} / \mathrm{L}$ and it is assumed (with $\mathrm{z}^{\prime}$ denoting a positive parameter) that

(3”) $\mathrm{L}^{\prime} / \mathrm{L}=\left(1 / \mathrm{z}^{\prime}\right) \mathrm{Z}^{\prime \prime}$ :

$\left(3^{\prime \prime} .1\right) z^{\prime \prime}=z^{\prime} L^{\prime} / L$

Hence one obtains:

(3”.2) z“'Y = z’L’y

Real GDP (Y) is assumed to be represented by the equation $Y=\left(1-z^{\prime \prime}\right) K^{\beta}(A L)^{1-\beta}$ and abroad by $\mathrm{Y}^{*}=\left(1-\mathrm{Z}^{* *}\right) \mathrm{K}^{* \beta^{*}}\left(\mathrm{~A}^{*} \mathrm{~L}^{*}\right)^{1-\beta^{*}}\left(0<\beta<1 ; 0<\beta^{*}<1\right)$; hence $\mathrm{R} \& \mathrm{D}$ output is considered as an intermediate input, which indeed was the standard view of the System of National Accounts until 2014. If one assumes profit maximization, and hence $\beta Y / K=r$ ( $r$ is the real interest rate and depreciation of capital is disregarded here in order to avoid tedious calculation; abroad $\beta^{*} \mathrm{Y}^{*} / \mathrm{K}^{*}=\mathrm{r}^{*}$ ), one may rewrite the equation for the knowledge production function as follows:

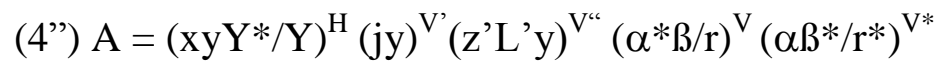

Rearranging the terms gives:

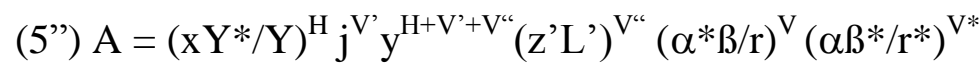

As can be seen, knowledge $A$ is explained by the ratio $\mathrm{Y}^{*} / \mathrm{Y}$, the import-GDP ratio $\mathrm{j}$, per capita income $y$, the size of the research labor force L' and the globalization parameters $\alpha^{*}$ and $\alpha$, respectively. One may define $H^{\prime \prime}:=H+V+V "$.

(6”) $\ln \mathrm{A}=\mathrm{H} \ln x+\mathrm{H} \ln \left(\mathrm{Y}^{*} / \mathrm{Y}\right)+\mathrm{V}^{\prime} \operatorname{lnj}+\mathrm{H}^{\prime \prime} \ln \mathrm{y}+\mathrm{V}^{\prime \prime}\left(\ln \mathrm{z}^{\prime}+\ln \mathrm{L}^{\prime}\right)+\mathrm{V}\left(\ln \alpha^{*}+\ln \beta-\ln r\right)+\mathrm{V}^{*}\left(\ln \alpha+\ln \beta^{*}-\ln \mathrm{r}^{*}\right)$

An empirical implementation could be - with $H^{\prime}=V^{\prime \prime} l n z '$ :

(7”) $\ln \mathrm{A}=\mathrm{H}^{\prime}+\mathrm{H} \ln \mathrm{x}+\mathrm{V}^{\prime} \operatorname{lnj}+\mathrm{H} \ln \left(\mathrm{Y}^{*} / \mathrm{Y}\right)+\mathrm{H}^{\prime \prime} \ln \mathrm{y}+\mathrm{V}^{\prime \prime} \ln \mathrm{L}^{\prime}+\mathrm{V}\left(\ln \alpha^{*}+\ln \beta-\ln r\right)+\mathrm{V}^{*}\left(\ln \alpha+\ln \beta^{*}-\right.$ $\left.\ln { }^{*}\right)$ 
This is a compact theoretical basis for the empirical analysis of a knowledge production function with inward cumulated FDI and outward cumulated FDI; if one assumes, roughly in line with a Heckscher-Ohlin setting, that production technology at home is the same as abroad with respect to $\beta$ and $\beta^{*}\left(\beta=\beta^{*}\right)$, respectively, and if capital mobility brings about $\mathrm{r}=\mathrm{r}^{*}$, a setup with $\mathrm{V}=\mathrm{V}^{\text {“ }}$ allows to consider the simplified equation for empirical implementation (otherwise the more complex version would have to be used):

(8”) $\ln \mathrm{A}=\mathrm{H}^{\prime}+\mathrm{H} \ln \mathrm{x}+\mathrm{V}^{\prime} \operatorname{lnj}+\mathrm{H} \ln \left(\mathrm{Y}^{*} / \mathrm{Y}\right)+\mathrm{H}^{\prime \prime} \ln y+\mathrm{V}^{\prime \prime} \ln L^{\prime}+\mathrm{V} \ln \alpha^{*}+\mathrm{V} \ln \alpha$

Trade globalization would show up in the form of a rise of $\mathrm{x}$ and $\mathrm{j}$, and FDI globalization in the form of a rise of $\alpha^{*}$ and $\alpha$, respectively. While this formulation of the knowledge production formation is fairly straightforward, it is a priori not clear how well the empirical implementation will work. It is noteworthy that one may define a global economic equilibrium through the condition that $\mathrm{Y}^{*} / \mathrm{Y}$ as well as the parameters $\mathrm{x}, \mathrm{j}, \alpha, \alpha^{*}$ should be constant. If $\mathrm{Y} /(\mathrm{AL}):=\mathrm{y}$ ' would be constant in a steady state situation, the implication then is - taking into account that lny' $=\ln \mathrm{y}-\ln \mathrm{A}-$ that the equation obviously implies $(1-\mathrm{H}) \mathrm{d} \ln \mathrm{A} / \mathrm{dt}=\mathrm{V}^{\prime} \mathrm{dlnL}^{\prime} / \mathrm{dt}$. Assuming that $0<\mathrm{H}<1$, the implication then is that the long run steady state growth rate of knowledge is given by:

(9") $\mathrm{d} \ln \mathrm{A} / \mathrm{dt}=\mathrm{V} " /(1-\mathrm{H})] \mathrm{dln} \mathrm{L}^{\prime} / \mathrm{dt}$

This equation can be understood easily if one assumes that the growth rate of researchers $\mathrm{d} \operatorname{lnL}$ '/dt is constant, however, this implies skilled labor dynamics and human capital formation - assuming that research is skill-intensive. With respect to empirical analysis and panel data analysis, one may emphasize that OECD countries differ in the degree of two-way FDI intensity; many countries have relatively high FDI inflows, but rather small relative FDI outflows, but fixed country effects in panel data analysis should cover this and other aspects. For small open economies the analysis is rather straightforward, more complicated is the situation of international technology or macroeconomic interdependency. International technology interdependency could be related to technoglobalization (JUNGMITTAG, 2016; DACHS, 2016; DACHS ET AL., 2015) or to the oligopolistic international interdependency of multinational companies' production and $\mathrm{R} \& \mathrm{D}$ activities.

An important next analytical step is to then plug the basic knowledge production function $\left(1^{\prime \prime}\right) \mathrm{A}=(\mathrm{X} / \mathrm{L})^{\mathrm{H}}(\mathrm{J} / \mathrm{L})^{\mathrm{V}^{\prime}}\left(\mathrm{z}^{\prime \prime} \mathrm{Y}\right)^{\mathrm{V}^{\prime \prime}}\left(\alpha^{*} \mathrm{~K} / \mathrm{Y}\right)^{\mathrm{V}}\left(\alpha \mathrm{K}^{*} / \mathrm{Y}^{*}\right)^{\mathrm{V}^{*}}$ into the macroeconomic production function. Hence, export per capita $X / L$, import per capita $J / L$, the output of the R\&D sector, the inward FDI stock relative to GDP and the ratio of cumulated outward FDI to foreign GDP explain knowledge. However, in a competitive environment with a Cobb Douglas function in both countries it has to be remembered that (1") can be rearranged as (5”), namely in the following compact form $\mathrm{A}=\left(\mathrm{x} \mathrm{Y}^{*} / \mathrm{Y}\right)^{\mathrm{H}} \mathrm{j}^{\mathrm{V}^{\prime}} \mathrm{y}^{\mathrm{H}+\mathrm{V}^{\prime}+\mathrm{V}^{\prime \prime}}\left(\mathrm{z}^{\prime} \mathrm{L}^{\prime}\right)^{\mathrm{V}^{\prime \prime}}\left(\alpha^{*} \beta / \mathrm{r}\right)^{\mathrm{V}}$ $\left(\alpha \beta^{*} / \mathrm{r}^{*}\right)^{\mathrm{V}^{*}}$. This formulation, which shows the impact of $\mathrm{Y}^{*} / \mathrm{Y}$, of per capita income, of researchers and of the inward FDI capital variable as well as the outward FDI capital variable - plus $x$ and $j$ as indicators of trade intensity, is the key point of departure for the 
next section. With respect to a more general knowledge production function - and its empirical implementation - an alternative formulation of the knowledge production function could be the equation $\mathrm{A}=(1+\mathrm{X} / \mathrm{L})^{\mathrm{H}}(1+\mathrm{J} / \mathrm{L})^{\mathrm{V}^{\prime}}\left(\mathrm{z}^{\text {" }} \mathrm{Y}\right)^{\mathrm{V} \text { " }}\left(1+\alpha^{*} \mathrm{~K} / \mathrm{Y}\right)^{\mathrm{V}}$ $\left(1+\alpha \mathrm{K}^{*} / \mathrm{Y}^{*}\right)^{\mathrm{V}^{*}}$ so that the case of a closed economy with no trade and no foreign direct investment could also be covered.

\section{The Schumpeterian Macroeconomic Production Function}

The Schumpeterian Macro Production Function (SMPF) is obtained from plugging the knowledge production function into the macroeconomic production function. For the sake of simplicity a Cobb Douglas production function $Y=\left(1-z^{\prime \prime}\right) K^{\beta}(A L)^{1-\beta}$ will be considered and it is assumed here that the share $z^{\text {" of }} \mathrm{R} \& \mathrm{D}$ output in GDP is an intermediate product. The knowledge production function is $\mathrm{A}\left(\mathrm{Y}^{*} / \mathrm{Y}, \mathrm{y}, \mathrm{L}, \alpha, \alpha^{*}, \mathrm{j}, \mathrm{x}\right)$ where all partial derivatives are positive. Using the rather compact specification of the knowledge production function developed here, one can easily plug it into the macroeconomic production function and in the end get a macroeconomic long run supply function (with L' denoting the number of researchers):

$Y=Y\left(K, L, L^{\prime}, Y^{*}, \alpha, \alpha^{*}, x, j\right)$

The partial derivatives are all positive. Hence let us consider the explicit result of plugging the knowledge production function for the open economy into the macroeconomic production function wich gives the integrated Schumpeterian production function (with nested knowledge production function $\mathrm{A}(\ldots))$ :

(I) $Y=\left(1-z^{\prime \prime}\right) K^{\beta}(A L)^{1-\beta}$

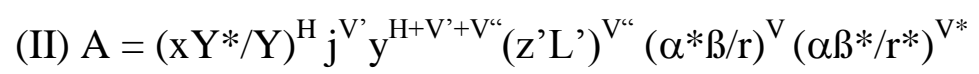

(III)

$$
\begin{aligned}
& Y=\left(1-z^{\prime \prime}\right) K^{\beta}\left(\left(\mathrm{x} \frac{\mathrm{Y}^{*}}{\mathrm{Y}}\right)^{\mathrm{H}} \mathrm{j}^{\mathrm{V}^{\prime}}\left(\frac{\mathrm{Y}}{L}\right)^{\mathrm{H}+\mathrm{V}^{\prime}+\mathrm{V}^{\prime \prime}}\left(\mathrm{z}^{\prime} \mathrm{L}^{\prime}\right)^{\mathrm{V}^{\prime \prime}}\left(\alpha^{*} \beta / \mathrm{r}\right)^{\mathrm{V}}\left(\alpha \beta^{*} / \mathrm{r}^{*}\right)^{\mathrm{V}^{*}} L\right)^{1-\beta}= \\
& =\left(1-z^{\prime \prime}\right) K^{\beta}\left(x^{H} \mathrm{Y}^{* H} Y^{-H} \mathrm{j}^{\mathrm{V}^{\prime}} \mathrm{Y}^{\mathrm{H}+\mathrm{V}^{\prime}+\mathrm{V}^{\prime \prime}}\left(\frac{1}{L}\right)^{\mathrm{H}+\mathrm{V}^{\prime}+\mathrm{V}^{\prime \prime}}\left(\mathrm{z}^{\prime} \mathrm{L}^{\prime}\right)^{\mathrm{V}^{\prime}}\left(\alpha^{*} \beta / \mathrm{r}\right)^{\mathrm{V}}\left(\alpha \beta * / \mathrm{r}^{*}\right)^{\mathrm{V}^{*}} L\right)^{1-\beta}= \\
& =\left(1-z^{\prime \prime}\right) K^{\beta} \mathrm{Y}^{\left(\mathrm{V}^{\prime}+\mathrm{V}^{\prime \prime}\right)(1-\beta)}\left(x^{H} \mathrm{Y}^{*} H \mathrm{j}^{\prime}\left(\frac{1}{L}\right)^{\mathrm{H}+\mathrm{V}^{\prime}+\mathrm{V}^{\prime \prime}}\left(\mathrm{z}^{\prime} \mathrm{L}^{\prime}\right)^{\mathrm{V}^{\prime \prime}}\left(\alpha^{*} \beta / \mathrm{r}\right)^{\mathrm{V}}\left(\alpha \beta^{*} / \mathrm{r}^{*}\right)^{\mathrm{V}^{*}} L\right)^{1-\beta}= \\
& =\left(1-z^{\prime \prime}\right) K^{\beta} \mathrm{Y}^{\left(\mathrm{V}^{\prime}+\mathrm{V}^{“}\right)(1-\beta)}\left(x^{H} \mathrm{Y}^{* H} \mathrm{j}^{\mathrm{V}^{\prime}} L^{1-\mathrm{H}-\mathrm{V}^{\prime}-\mathrm{V}^{\prime \prime}}\left(\mathrm{z}^{\prime} \mathrm{L}^{\prime}\right)^{\mathrm{V}^{\mathrm{\prime}}}\left(\alpha^{*} \beta / \mathrm{r}\right)^{\mathrm{V}}\left(\alpha \beta^{*} / \mathrm{r}^{*}\right)^{\mathrm{V}^{*}}\right)^{1-\beta} \\
& Y^{1-\left(\mathrm{V}^{\prime}+\mathrm{V}^{\prime \prime}\right)(1-\beta)}=\left(1-z^{\prime \prime}\right) K^{\beta}\left(x^{H} \mathrm{Y}^{* H} \mathrm{j}^{\mathrm{V}^{\prime}} L^{1-\mathrm{H}-\mathrm{V}^{\prime}-\mathrm{V}^{\prime \prime}}\left(\mathrm{z}^{\prime} \mathrm{L}^{\prime}\right)^{\mathrm{V}^{\prime \prime}}\left(\alpha^{*} \beta / \mathrm{r}\right)^{\mathrm{V}}\left(\alpha \beta * / \mathrm{r}^{*}\right)^{\mathrm{V}^{*}}\right)^{1-\beta}
\end{aligned}
$$




$$
Y=\left(\left(1-z^{\prime \prime}\right) K^{\beta}\left(x^{H} \mathrm{Y}^{* H} \mathrm{j}^{\mathrm{V}^{\prime}} L^{1-\mathrm{H}-\mathrm{V}^{\prime}-\mathrm{V}^{\prime \prime}}\left(\mathrm{z}^{\prime} \mathrm{L}^{\prime}\right)^{\mathrm{V}^{\prime \prime}}\left(\alpha^{*} \beta / \mathrm{r}\right)^{\mathrm{V}}\left(\alpha \beta * / \mathrm{r}^{*}\right)^{\mathrm{V}^{*}}\right)^{1-\beta}\right)^{\frac{1}{1-\left(\mathrm{V}^{\prime}+\mathrm{V}^{\prime \prime}\right)(1-\beta)}}
$$

$$
\begin{aligned}
& Y=\left(\left(1-z^{\prime \prime}\right) K^{\beta}\left(x^{H} \mathrm{Y}^{* H} \mathrm{j}^{\mathrm{V}^{\prime}} L^{1-\mathrm{H}-\mathrm{V}^{\prime}-\mathrm{V}^{\prime \prime}}\left(\mathrm{z}^{\prime} \mathrm{L}^{\prime}\right)^{\mathrm{V}^{\prime \prime}}\left(\alpha^{*} \beta / \mathrm{r}\right)^{\mathrm{V}}\left(\alpha \beta^{*} / \mathrm{r}^{*}\right)^{\mathrm{V}^{*}}\right)^{1-\beta}\right)^{\frac{1}{1-\left(\mathrm{V}^{\prime}+\mathrm{V}^{\prime \prime}\right)(1-\beta)}} \\
& Y=\left(1-z^{\prime \prime}\right)^{\frac{1}{1-\left(\mathrm{V}^{\prime}+\mathrm{V}^{\prime \prime}\right)(1-\beta)}} K^{\frac{\beta}{1-\left(\mathrm{V}^{\prime}+\mathrm{V}^{\prime \prime}\right)(1-\beta)}}\left(x^{H} \mathrm{Y}^{* H} \mathrm{j}^{\mathrm{V}^{\prime}} L^{1-\mathrm{H}-\mathrm{V}^{\prime}-\mathrm{V}^{\prime \prime}}\left(\mathrm{z}^{\prime} \mathrm{L}^{\prime}\right)^{\mathrm{V}^{\prime \prime}}\left(\alpha^{*} \beta / \mathrm{r}\right)^{\mathrm{V}}\left(\alpha \beta * / \mathrm{r}^{*}\right)^{\mathrm{V}^{*}}\right)^{\frac{1-\beta}{1-\left(\mathrm{V}^{\prime}+\mathrm{V}^{\prime \prime}\right)(1-\beta)}} \\
& \ln Y=\frac{1}{1-\left(\mathrm{V}^{\prime}+\mathrm{V}^{“}\right)(1-\beta)} \ln \left(1-z^{\prime \prime}\right)+\frac{\beta}{1-\left(\mathrm{V}^{\prime}+\mathrm{V}^{\prime \prime}\right)(1-\beta)} \ln K \\
& +\frac{1-\beta}{1-\left(\mathrm{V}^{\prime}+\mathrm{V}^{\prime \prime}\right)(1-\beta)} \ln \left(x^{H} \mathrm{Y}^{* H} \mathrm{j}^{\mathrm{V}^{\prime}} L^{1-\mathrm{H}-\mathrm{V}^{\prime}-\mathrm{V}^{\prime \prime}}\left(\mathrm{z}^{\prime} \mathrm{L}^{\prime}\right)^{\mathrm{V}^{\prime \prime}}\left(\alpha^{*} \beta / \mathrm{r}\right)^{\mathrm{V}}\left(\alpha \beta^{*} / \mathrm{r}^{*}\right)^{\mathrm{V}^{*}}\right)= \\
& \frac{1}{1-\left(\mathrm{V}^{\prime}+\mathrm{V}^{\prime \prime}\right)(1-\beta)}\left\{\ln \left(1-z^{\prime \prime}\right)+\beta \ln K+\right. \\
& \left.+(1-\beta)\left[H \ln x+H \ln \mathrm{Y}^{*}+V^{\prime} \ln j+\left(1-\mathrm{H}-\mathrm{V}^{\prime}-\mathrm{V}^{“}\right) \ln L+V^{\prime \prime} \ln \left(\mathrm{z}^{\prime} \mathrm{L}^{\prime}\right)+V \ln \left(\alpha^{*} \beta / \mathrm{r}\right)+V^{*} \ln \left(\alpha \beta^{*} / \mathrm{r}^{*}\right)\right]\right\}
\end{aligned}
$$

It is obvious from the logarithmic equation that a positive growth rate $d \ln \left(\mathrm{L}^{\prime} / \mathrm{L}\right)$ will contibute to economic output growth in the long run. To get a better understanding as to what extent the level of the growth path and the trend growth rate itself will be affected one will have to consider a modified neoclassical growth model.

The result obtained for the Schumpeterian macroeconomic production function looks fairly compact. Real gross domestic product is a positive function of

- the capital stock

- the export-GDP ratio; and foreign GDP

- the import-GDP ratio

- total labor

- the share of researchers in the total labor force

- the ratio of the inward FDI capital stock relative to the total capital stock

- the ratio of the outward FDI capital stock relative to the total capital stock abroad;

- the real interest rate at home and abroad has a negative impact on the production potential.

The latter is quite interesting since it allows a direct link to the real money supply: if money market equilibrium - in an economy with a stable price level at home and abroad is written as $\mathrm{M} / \mathrm{P}=\mathrm{hY} /\left(\mathrm{h}{ }^{\prime} \mathrm{r}\right)$ in the home country and as $\mathrm{M} * / \mathrm{P} *=\mathrm{h}^{*} \mathrm{Y} * /\left(\mathrm{h}^{*} \mathrm{r}^{*}\right)$ in country 2 (with positive parameters $h, h^{\prime}, h^{*}$ and $h^{\prime *}$ ), one gets $r=h Y /\left(h^{\prime} M / P\right.$ ) and $r^{*}=$ $\mathrm{h}^{*} \mathrm{Y}^{*} /\left(\mathrm{h}^{*} \mathrm{M}^{*} / \mathrm{P}^{*}\right)$, respectively, and thus obtains an analytical basis for monetary growth models; defining $h / h$ ': $=h^{\prime \prime}$ and $h * / h{ }^{*}=h^{* *}$, one can see that real money balances at home and abroad are contributing to real GDP in an open economy with inward and outward FDI 
(an alternative new approach in a closed economy has been suggested by WELFENS (2011) who considers real monetary balances held by private households as an implicit production factor of firms, namely on the basis of positive external effects for companies). Real GDP thus can be written as follows:

$$
\begin{aligned}
& Y=\left(1-z^{\prime \prime}\right)^{\frac{1}{1-\left(V^{\prime}+V^{\prime \prime}\right)(1-\beta)}} K^{\frac{\beta}{1-\left(V^{\prime}+V^{\prime}\right)(1-\beta)}}\left(x^{H} Y^{* H} j^{V^{\prime}} L^{1-H-V^{\prime}-V^{\prime \prime}}\left(z^{\prime} L^{\prime}\right)^{V^{\prime \prime}}\left(\alpha^{*} \beta / r\right)^{V}\left(\alpha \beta^{*} / r^{*}\right)^{V^{*}}\right)^{\frac{1-\beta}{1-\left(V^{\prime}+V^{\prime}\right)(1-\beta)}} \\
& Y=\left(1-z^{\prime \prime}\right) \frac{1}{1-\left(V^{\prime}+V^{\prime \prime}\right)(1-\beta)} K^{\frac{\beta}{1-\left(V^{\prime}+V^{*}\right)(1-\beta)}}\left(x^{H} Y^{*} j^{V^{\prime}} L^{1-H^{\prime}-V^{\prime}-V^{\prime \prime}}\left(z^{\prime} L^{\prime}\right)^{V^{\prime}}\left(\frac{\alpha^{*} \beta h^{\prime} M}{Y h P}\right)^{V}\left(\frac{\alpha \beta^{*} h^{*} M^{* *}}{h^{*} Y^{*} P^{*}}\right)^{V^{*}}\right)^{\frac{1-\beta}{1-\left(V^{\prime}+\beta^{\prime}\right)(1-\beta)}} \\
& Y^{\frac{1-(1-\beta)\left[V^{\prime}+V^{\prime \prime}+V\right]}{1-\left(V^{\prime}+V^{\prime \prime}\right)(1-\beta)}}=\left(1-z^{\prime \prime}\right)^{\frac{1}{1-\left(V^{\prime}+V^{\prime \prime}\right)(1-\beta)}} K^{\frac{\beta}{1-\left(V^{\prime}+V^{\prime}\right)(1-\beta)}}\left(x^{H} Y^{*} j^{V^{\prime}} L^{1-H^{\prime}-V^{\prime}-V^{\prime \prime}}\left(z^{\prime} L^{\prime}\right)^{V^{\prime \prime}}\left(\frac{\alpha^{*} \beta h^{\prime} M}{h P}\right)^{V}\left(\frac{\alpha \beta^{*} h^{*^{*}} M^{*^{*}}}{h^{*} Y^{*} P^{*}}\right)^{V^{*}}\right)^{\frac{1-\beta}{1-\left(V^{\prime}+V^{\prime}\right)(1-\beta)}} \\
& Y=\left\{\left(1-z^{\prime \prime}\right)^{\frac{1}{1-\left(V^{\prime}+V^{\prime \prime}\right)(1-\beta)}} K^{\frac{\beta}{1-\left(V^{\prime}+V^{*}\right)(1-\beta)}}\left(x^{H} Y^{*} j^{V^{\prime}} L^{1-H^{\prime}-V^{\prime}-V^{\prime \prime}}\left(z^{\prime} L^{\prime}\right)^{V^{\prime \prime}}\left(\frac{\alpha^{*} \beta h^{\prime} M}{h P}\right)^{V}\left(\frac{\alpha \beta^{*} h^{*} M^{* *}}{h^{*} Y^{*} P^{*}}\right)^{V^{*}}\right)^{\frac{1}{1-\left(V^{\prime}+V^{*}\right)(1-\beta)}}\right\}^{\frac{1-\left(V^{\prime}+V^{\prime \prime}\right)(1-\beta)}{1-(1-\beta)\left[V^{\prime}+V^{*}+V\right]}} \\
& Y=\left(1-z^{\prime \prime}\right)^{\frac{1}{1-(1-\beta)\left[V^{\prime}+V^{*}+V\right]}} K^{\frac{\beta}{1-(1-\beta)\left[V^{\prime}+V^{\prime \prime}+V\right]}}\left(x^{H} Y^{*} H j^{V^{\prime}} L^{1-H-V^{\prime}-V^{\prime \prime}}\left(z^{\prime} L^{\prime}\right)^{V^{\prime \prime}}\left(\frac{\alpha^{*} \beta h^{\prime} M}{h P}\right)^{V}\left(\frac{\alpha \beta^{*} h^{\prime^{*}} M^{* *}}{h^{*} Y^{*} P^{*}}\right)^{V^{*}}\right)^{\frac{1-\beta}{1-(1-\beta)\left[V^{\prime}+V^{*}+V\right]}}
\end{aligned}
$$

There are two key insights here:

- The real GDP thus is a positive function of both real money balances at home $(\mathrm{M} / \mathrm{P})$ and real money balances abroad $\left(\mathrm{M}^{*} / \mathrm{P}^{*}\right)$.

- The exponent for $\mathrm{K}$ and the exponent for the large bracket term is smaller than before so that taking into account money market equilibrium conditions at home and abroad implies that the effective output elasticity with respect to capital and all variables in the large bracket terms is smaller than before.

This effective Schumpeterian production potential could be the basis for a new monetary growth model (one may, however, argue that a true monetary growth model should be based on a production function in which $\mathrm{M} / \mathrm{P}$ enters directly as a productive input, namely in the form of positive external effects of households' holding of real money balances M/P: WELFENS, 2011).

Let us return to the formulation of the production potential with $\mathrm{r}$ and $\mathrm{r}^{*}$. It is obvious here that if $\mathrm{Y}^{*}$ is growing in a sustained way - hence the foreign economy is already in a steady state - the implication is that the home economy is growing too; and here exports are the key driver. As the long run level of output growth is a negative function of the real interest rate, monetary policy can be considered in a quasi-monetary growth approach: If the equilibrium condition for the money market is $\mathrm{M} / \mathrm{P}=\mathrm{hY} /(\mathrm{h}$ 'r), monetary policy - defined as a change of $(\mathrm{M} / \mathrm{P}) / \mathrm{Y}$ - can reduce the real interest rate, the level of output and thus raise output. Moreover, it can be shown that the effective Schumpeterian macro production function implies that output per capita for the special case of $\beta=0.5$ is a positive function of 
capital intensity, the ratio of $R \& D$ workers in the total labor force, exports per capita, imports per capita, inward FDI intensity $(\alpha)$ and outward FDI intensity $\left(\alpha^{*}\right)$. For the general case $0<\beta<1$ the function is more complicated. The special case of $\beta=0.5$ allows to develop a Schumpeterian Solow growth model on the assumption that $\mathrm{Y}^{*} / \mathrm{Y}$ is constant and $L^{\prime}$ is increasing at a constant rate.

\subsection{Output Elasticity with Respect to Foreign Knowledge}

If one wants to understand the role of foreign knowledge on country 1's output one has to consider the knowledge production function and the macroeconomic production in both country 1 and country 2 ; recall the knowledge production function $(1$ " $) A=(X / L)^{\mathrm{H}}(\mathrm{J} / \mathrm{L})^{\mathrm{V}}$ $\left(\mathrm{z}^{\prime \prime} \mathrm{Y}\right)^{\mathrm{V} \text { “" }}\left(\alpha^{*} \mathrm{~K} / \mathrm{Y}\right)^{\mathrm{V}}\left(\alpha \mathrm{K}^{*} / \mathrm{Y}^{*}\right)^{\mathrm{V}^{*}}$ and the formulation $\left(5^{\prime \prime}\right) \mathrm{A}=(\mathrm{xY} / \mathrm{Y})^{\mathrm{H}} \mathrm{j}^{\mathrm{V}^{\prime}} \mathrm{y}^{\mathrm{H}+\mathrm{V}^{\prime}+\mathrm{V}^{\prime \prime}}\left(\mathrm{z}^{\prime} \mathrm{L}^{\prime}\right)^{\mathrm{V}^{\prime \prime}}$ $\left(\alpha^{*} \beta / \mathrm{r}\right)^{\mathrm{V}}\left(\alpha \beta^{*} / \mathrm{r}^{*}\right)^{\mathrm{V}^{*}}$. Let us define $\mathrm{v}:=1-\left(\mathrm{V}^{\prime}+\mathrm{V}^{\prime \prime}\right)(1-\beta)$. Hence

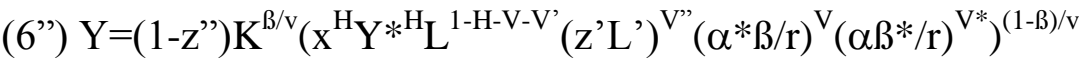

As $\mathrm{Y}^{*}=\left(1-\mathrm{z}^{* *}\right) \mathrm{K}^{* \beta}\left(\mathrm{A}^{*} \mathrm{~L}^{*}\right)^{1-\beta}$ we get:

(7”) $Y=\left(1-z^{\prime \prime}\right) K^{\beta / v}\left(\left(x^{H}\left(1-z^{\prime *}\right) K^{* \beta H}\left(A^{*} L^{*}\right)^{\left(1-\beta^{*}\right) H} L^{1-H-V-V^{\prime}}\left(z^{\prime} L^{\prime}\right)^{V^{\prime \prime}}\left(\alpha^{*} \beta / r\right){ }^{V}\left(\alpha \beta^{*} / r\right)^{V^{*}}\right)^{(1-\beta) / v}\right.$

From this follows for the effective elasticity of output with respect to foreign knowledge that

(8”) $\mathrm{d} \ln \mathrm{Y} / \mathrm{d} \ln \mathrm{A}^{*}=\left(1-\beta^{*}\right) \mathrm{H}(1-\beta) / \mathrm{v}=\left(1-\beta^{*}\right) \mathrm{H}(1-\beta) /\left(1-\left(\mathrm{V}^{\prime}+\mathrm{V}^{\prime \prime}\right)(1-\beta)\right)=$

$=\left(1-\beta^{*}\right) \mathrm{H} /\left((1-\beta)^{-1}-\left(\mathrm{V}^{\prime}+\mathrm{V}^{\prime \prime}\right)\right)$

Thus this elasticity of output with respect to foreign knowledge is a positive function of the export per capita elasticity $\mathrm{H}$ in the knowledge production function and a negative function of both $\beta^{*}$ and $B$ (the output elasticity of capital in the macroeconomic production function in country 1 and country 2 , respectively) as well as a positive function of the import per capita elasticity and the research output elasticity, respectively, in the knowledge production function. Thus the theoretical analysis allows getting a much better understanding of apparent international technology output effects.

\subsection{Endogenous Growth Model}

A growth model on the basis of a Schumpeterian macroeconomic production function can be derived here in a compact endogenous growth approach. Assume for simplicity that $\beta=1-\beta$ so that $\beta=0.5$. Hence we can write

(9) $\mathrm{y}:=\mathrm{Y} / \mathrm{L}=\left(1-\mathrm{z}^{\prime \prime}\right) \mathrm{k}^{0.5 / \mathrm{v}}\left(\left(\mathrm{x}^{\mathrm{H}} \mathrm{Y}^{* \mathrm{H}} \mathrm{L}^{-\mathrm{H}-\mathrm{V}-\mathrm{V}^{\prime}}\left(\mathrm{z}^{\prime} \mathrm{L}^{\prime}\right)^{\mathrm{V}{ }^{\prime \prime}}\left(\alpha^{*} \beta / \mathrm{r}\right)^{\mathrm{V}}\left(\alpha \beta^{*} / \mathrm{r}\right)^{\mathrm{V} *}\right)^{0.5 / \mathrm{v}}\right.$

Let us define $\mathrm{Q}:=\left(\left(\mathrm{x}^{\mathrm{H}} \mathrm{Y}^{*}{ }^{\mathrm{H}} \mathrm{L}^{-\mathrm{H}-\mathrm{V}-\mathrm{V}^{\prime}}\left(\mathrm{z}^{\prime} \mathrm{L}^{\prime}\right)^{\mathrm{V}^{\prime}}\left(\alpha^{*} \beta / \mathrm{r}\right)^{\mathrm{V}}\left(\alpha \beta^{*} / \mathrm{r}\right)^{\mathrm{V} *}\right)\right.$

Goods market equilibrium condition in an economy with zero depreciation and constant growth of labor (growth rate $\mathrm{n} ; \mathrm{k}:=\mathrm{K} / \mathrm{L}$, income tax rate is $\tau$ ) is given by:

(10) $d K / d t+z^{\prime c} Y=s(1-\tau) Y$ 
For simplicity the savings function assumed here is $s(1-\tau) Y$. Hence we get for the case of an exogenous growth rate of $\mathrm{L}$, namely $\mathrm{n}$ (\# for steady state; $\mathrm{L}(\mathrm{t})=\mathrm{L}_{0} \mathrm{e}^{\text {, nt }}$, where $\mathrm{e}^{\prime}$ is the Euler number and $t$ is the time index):

(11) $\mathrm{dk} / \mathrm{dt}=\left(\mathrm{s}(1-\tau)-\mathrm{z}^{\mathrm{c}}\right)\left(1-\mathrm{z}^{6}\right) \mathrm{k}^{0.5 / \mathrm{v}} \mathrm{Q}^{0.5 / \mathrm{v}}-\mathrm{nk} ; 0<\beta / \mathrm{v}<1 ; \mathrm{n}>0$

(12) $\mathrm{k \#}=\mathrm{Q}^{0.5 / \mathrm{v}}\left(\left(\mathrm{s}(1-\tau)-\mathrm{z}^{\mathrm{c}}\right)\left(1-\mathrm{z}^{\mathrm{c}}\right) / \mathrm{n}\right)^{1 /(1-0.5 / \mathrm{v})}$;

(13) $\mathrm{y} \#=\mathrm{Q}^{0.5 / \mathrm{v}}\left(1-\mathrm{z}^{6}\right)\left(\left(\mathrm{s}(1-\tau)-\mathrm{z}^{\mathrm{c}}\right)\left(1-\mathrm{z}^{\mathrm{c}}\right) / \mathrm{n}\right)^{(0.5 / \mathrm{v}) /(1-0.5 / \mathrm{v})} \mathrm{Q}^{0.5 / \mathrm{v}}$

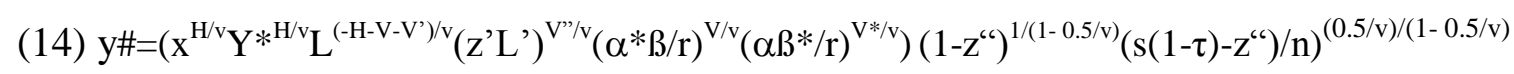

One can rewrite $\mathrm{Y}^{*} / \mathrm{L}$ as $\left(\mathrm{Y}^{*} / \mathrm{L}^{*}\right)\left(\mathrm{L}^{*} / \mathrm{L}\right)$ and - with $\mathrm{y}^{*}:=\mathrm{Y}^{*} /\left(\mathrm{A}^{*} \mathrm{~L}^{*}\right)$ - therefore $\mathrm{Y} / \mathrm{L}=$ $\mathrm{y}^{\prime} * \mathrm{~A}{ }_{0} \mathrm{e} \mathrm{a}^{* \mathrm{t}}$. Therefore one can restate the equation as follows:

(15) $\mathrm{y} \#=\left(\mathrm{x}^{\mathrm{H} / \mathrm{v}} \mathrm{y}^{* \mathrm{H} / \mathrm{v}}\left(\mathrm{L}^{*} / \mathrm{L}\right)^{\mathrm{H} / \mathrm{v}} \mathrm{L}^{\left(\mathrm{V}^{\prime \prime}-\mathrm{H}-\mathrm{V}-\mathrm{V}^{\prime}\right) \mathrm{H} / \mathrm{v}}\left(\mathrm{z}^{\prime} \mathrm{L} / \mathrm{L}\right)^{\mathrm{V}^{\prime \prime / v}}\left(\alpha^{*} \beta / \mathrm{r}\right)^{\mathrm{V} / \mathrm{v}}\left(\alpha \beta^{* / r}\right)^{\mathrm{V}^{* / \mathrm{v}}}\right)$

$\left.\left(1-\mathrm{Z}^{6 \mathrm{c}}\right)^{1 /(1-0.5 / \mathrm{v})}\left(\mathrm{s}(1-\tau)-\mathrm{z}^{6 \mathrm{u}}\right) / \mathrm{n}\right)^{(0.5 / \mathrm{v}) /(1-0.5 / \mathrm{v})}$

If abroad $\mathrm{S}^{*}=\left(1-\tau^{*}\right) \mathrm{Y}^{*}$ and - assuming that $\mathrm{d} \ln \left(\mathrm{A}^{*}\right) / \mathrm{dt}=\mathrm{a}^{*}$ and constant and $\mathrm{n}^{*}$ is constant

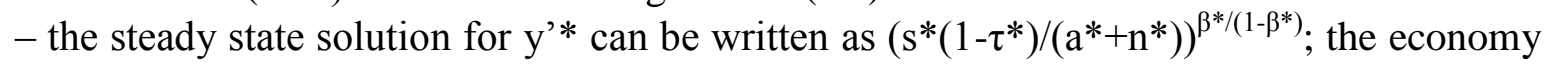
in country 2 for the sake of simplicity thus is characterized by a standard neoclassical (Solow) growth model result.

(16) $\left.y \#=\left(x^{H / v}\left(s^{*}\left(1-\tau^{*}\right) /\left(a^{*}+n^{*}\right)\right)^{\beta^{*} H /\left(1-\beta^{*}\right) / v}\left(L^{*} / L\right)^{H / v}\left(z^{\prime} L ' / L\right)^{V^{\prime \prime / v}}\left(\alpha^{*} \beta / r\right)\right)^{\mathrm{V} / \mathrm{v}}\left(\alpha \beta^{*} / r\right)^{\mathrm{V}^{* / v}}\right)$

$\left.\left(1-\mathrm{Z}^{6}\right)^{1 /(1-0.5 / \mathrm{v})}\left(\mathrm{s}(1-\tau)-\mathrm{Z}^{6}\right) / \mathrm{n}\right)^{(0.5 / \mathrm{v}) /(1-0.5 / \mathrm{v})} L_{0}{ }^{\left(\mathrm{V} "-\mathrm{H}-\mathrm{V}-\mathrm{V}{ }^{\prime}\right) \mathrm{HV}}{ }^{\prime \prime /(\mathrm{vv})} A^{*}{ }_{0}{ }^{H / v} e^{,\left(a^{*}+n\right)(H / v) t}$

Thus, the steady state growth rate of $y$ is $\left(a^{*}+n\right)(H / v)$.

\subsection{Golden Rule}

The golden rule that maximizes per capita consumption is given by the condition $\mathrm{dY} / \mathrm{dK}$ $=\left(a^{*}+n\right)(H / v)$ and, recalling the definition of $v:=1-\left(V^{\prime}+V^{\prime \prime}\right)(1-\beta)$, therefore also by the condition:

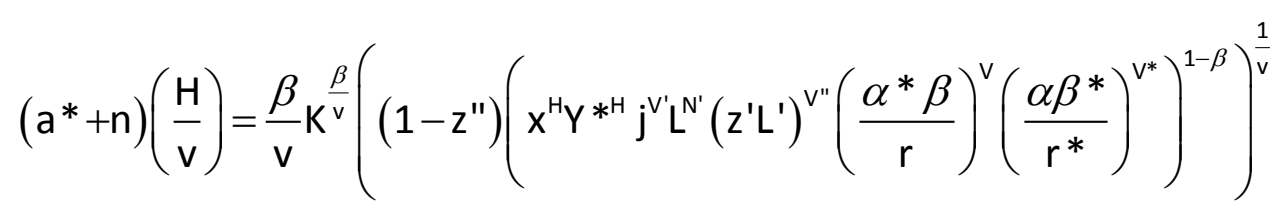

If one assumes profit maximization in the form marginal product of capital $Y_{K}=r$ ( $r$ is the real interest rate) the implication is that $r=\left(a^{*}+n\right)(H / v)$ which is quite interesting since in the case of a big country 2 the reading is that the real interest rate is determined by the foreign variable $\mathrm{a}^{*}$ and the domestic population growth rate $\mathrm{n}$ as well as the parameters $\mathrm{H}$ and $\mathrm{v}$; recall $\mathrm{v}:=1-\left(\mathrm{V}^{\prime}+\mathrm{V}^{\prime}\right)(1-\beta)$ so that four supply side parameters determine $\mathrm{r}$ in this new setup, namely the output elasticity $\beta$ negatively while the knowledge production 
parameters $\mathrm{H}, \mathrm{V}^{\prime}$ and $\mathrm{V}$ " have a positive impact on the real interest rate. It is noteworthy that a rise of $\beta-$ e.g. caused by the expansion of information and communication technology - will reduce the real interest rate.

\subsection{Labor Market Demand and other Macro Aspects}

The marginal product of overall labor $\mathrm{Y}_{\mathrm{L}}$ is given by (with $\mathrm{N}^{\prime}:=1-\mathrm{H}-\mathrm{V}-\mathrm{V}^{\prime}$ ):

$$
Y_{L}=\frac{N^{\prime}(1-\beta)}{v} L^{\frac{(1-\beta)\left(1-H-V+V^{\prime \prime}\right)-1}{v}}\left(\left(1-z^{\prime \prime}\right) K^{\beta}\left(x^{H} Y^{* H} j^{V^{\prime}}\left(z^{\prime} L^{\prime}\right) V^{V^{\prime \prime}}\left(\frac{\alpha^{*} \beta}{r}\right)^{v}\left(\frac{\alpha \beta^{*}}{r^{*}}\right)^{V^{*}}\right)^{1-\beta}\right)^{\frac{1}{v}}
$$

Clearly, obviously the marginal product of labor is a positive function of both the domestic and foreign capital stock, the foreign level of knowledge, the employment abroad, the number of researchers, the inward FDI parameter $\alpha^{*}$, the outward FDI parameter $\alpha$

The demand for labor therefore is (with $\mathrm{N}^{\prime}:=1-\mathrm{H}-\mathrm{V}-\mathrm{V}^{\prime}$ ):

$L^{d}=\left(\frac{v w}{N^{\prime}(1-\beta)}\right)^{\frac{v}{(1-\beta)\left(1-H-V+V^{\prime \prime}\right)-1}}\left(\left(1-z^{\prime \prime}\right) K^{\beta}\left(x^{H} Y^{* H} j^{V^{\prime}}\left(z^{\prime} L^{\prime}\right)^{V^{\prime \prime}}\left(\frac{\alpha * \beta}{r}\right)^{v}\left(\frac{\alpha \beta^{*}}{r^{*}}\right)^{V^{*}}\right)^{1-\beta}\right)^{-\frac{1}{(1-\beta)\left(1-H-V+V^{\prime \prime}\right)-1}}$

The demand for labor thus depends on many interesting variables. As regard the marginal product of capital it can be written as:

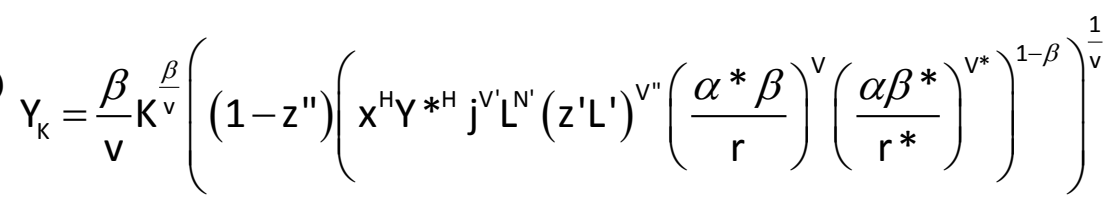

The marginal product of researchers is given by:

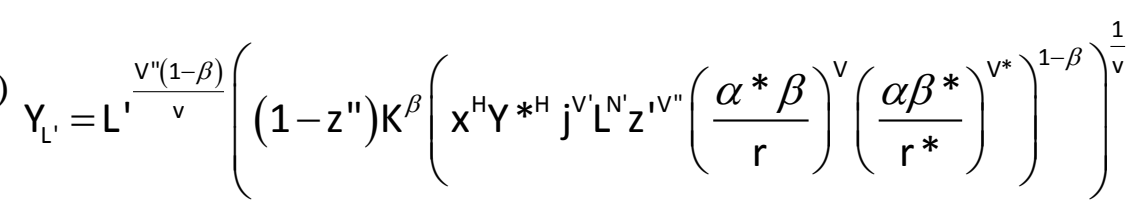

Denoting the nominal wage of researchers by $\mathrm{W}^{\prime}$ and the real wage by w', profit maximization will lead to $\mathrm{w}^{\prime}=\mathrm{Y}^{\mathrm{L}}$. Under profit maximization the implied demand for skilled labor (researchers )is given by the condition:

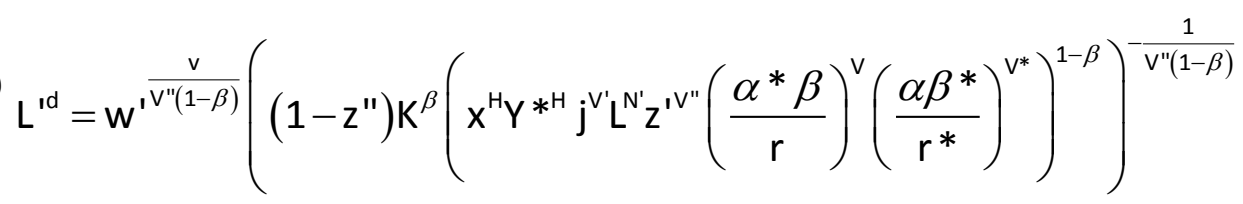

Thus one gets a comprehensive view for the case of an open economy on how many domestic and foreign influences affect the marginal product of labor and researchers, respectively.Trade intensity as well as FDI globalization parameters and foreign output determine the demand for researchers. 


\subsection{Hybrid Medium-Term Macro Model}

If in reality goods market equilibrium in the medium run is characterized on the aggregate demand side by both current income and steady state income (WELFENS, 2011) so that an adequate medium-term macro model would have to consider a weighted composite effective real income $Z$ (with $\Omega$ ' denoting the weighting factor of permanent income in the form of steady state income $\mathrm{Y} \#, 0<\mathrm{c}<1 ; 0<\mathrm{c}^{\prime}<1$; for the sake of simplicity no discounting of future income takes place and foreign GNP is already in the steady state). Assuming a Cobb-Douglas production function in each of the two countries considered, we can write for $\mathrm{Z}$ and $\mathrm{Z}^{*}$, respectively ( $\alpha$ denoting the share of capital owned by foreign investors from country 1 in country $2 ; \alpha^{*}$ denoting the share of capital owned by foreign investors from country 2 in country 1 ; and $\mathrm{q}^{*}:=\mathrm{eP}^{*} / \mathrm{P}$ where e is the nominal exchange and $\mathrm{P}$ the price level):

$$
\begin{aligned}
& Z=Y\left(1-\alpha^{*} \beta\right)+\alpha \beta^{*} Y^{*} q^{*} \\
& Z^{*}=Y^{*}\left(1-\alpha \beta^{*}\right)+\alpha^{*} \beta Y / q^{*}
\end{aligned}
$$

Here, gross national income is $\mathrm{Y}$ plus real net profit transfers from abroad - profits of country 2 subsidiaries amount to $\alpha^{*} \beta Y$ in country 1 provided there is competition in goods and factor markets. Profits accruing from subsidiaries abroad are $\alpha \beta^{*} Y^{*}$ and to express those profits in domestic goods units of country $1, \alpha \beta^{*} Y^{*}$ has to be multiplied by $\mathrm{q}^{*}$; profits of foreign subsidiaries in country 1 are $\alpha^{*} \beta Y$ in good units of country 1 (when expressed in goods units of country 2 , the term $\alpha^{*} \beta Y / q^{*}$ has to be considered). Hence if one assumes that consumption and imports are not proportionate to GDP but rather to $\mathrm{Z}-$ and exports to $Z^{*}$-, one can state as a medium-term condition for goods market equilibrium (WELFENS, 2011)

(25) $\mathrm{Y}=\left(1-\Omega^{\prime}\right) \mathrm{c}(1-\tau)\left(1-\alpha^{*} \beta\right) \mathrm{Y}+\Omega^{\prime} \mathrm{c}^{\prime}(1-\tau) \mathrm{Y} \#\left(1-\alpha^{*} \beta\right)+\mathrm{b}$ ' $(\beta \mathrm{Y} / \mathrm{K}-\mathrm{r})+\mathrm{G}+\mathrm{x}\left(\mathrm{Y}^{*} \#\left(1-\alpha \beta^{*}\right) \mathrm{q}^{*}\right.$ $+\alpha \beta Y)-j\left[\left(1-\Omega^{\prime}\right) \mathrm{c}(1-\tau) \mathrm{Y}\left(1-\alpha^{*} \beta\right)+\Omega^{\prime} \mathrm{c}^{\prime}(1-\tau)\left(1-\alpha^{*} \beta\right) \mathrm{Y} \#\right]$

The first term [...] on the right hand side is planned consumption. Exports depend, of course, on real income abroad and imports are a positive function of disposable real GNP (here the investment function is simply b" $(ß Y / K-r)$ and $G$ is government consumption. The difference between GDP (Y) and GNP (Z) is net income from abroad, namely profits obtained from subsidiaries abroad minus profits paid to foreign subsidiaries in country 1). It is obvious that the fiscal multiplier now looks different and that other multipliers also differ from traditional macro models. The steady state GDP has to be calculated from an endogenous growth model. One may also emphasize that $\Omega$ ' might have varying numbers over time, 1 if the economy is in the full employment steady state solution, between 0 and 1 otherwise. 


\subsection{Further Extensions}

There are many opportunities for additional research to be conducted. Since the Schumpeterian Macro Production Function includes $\mathrm{Y}^{*}$ on could also focus on a situation of an asymmetric international business cycle where country 1 is at full employment while country 2 is facing underutilization of the production potential so that $\mathrm{Y}^{*}$ could be covered by a Keynesian macro model with technology included - e.g. A* would enter the investment function and the export function (WELFENS, 2011). Moreover, in a full macro model with an additional equilibrium condition for the money market and the foreign exchange market one also will get new insights into the equilibrium exchange rate. To the extent that (with positive parameter b' and b") a medium term investment function $\mathrm{I}=$ $b^{\prime \prime}\left(Y_{K}-r\right)+b^{\prime}\left(A / A^{*}\right)$ is used the logic of the knowledge production function and the macroeconomic production function will enter even a compact open economy macro model via the investment function via both $\mathrm{Y}_{\mathrm{K}}$, $\mathrm{A}$ and $\mathrm{A}^{*}$; a compact export function (with positive parameters $x$ ' and $x$ ") could be $X=x Z^{*}+x^{\prime} A * / A+x$ " $q^{*}$ and the import function would read $J=j Z$ - j'A/A* - j"q* where j' and j" are positive parameters.

In an international full employment perspective it also is possible to model $\mathrm{Y}^{*}$ in an analogous way as $\mathrm{Y}$ in country 1 so that a Schumpeterian macroeconomic production function is relevant in country 1 and country 2: This is a useful approach to study long run international output interdependency. The production function as well as the knowledge production function could additionally include information and communication technology as a distinct input so that this important strand of research also could be analyzed in future research in a more consistent open economy context - possibly including international spillover effects plus network effects.

\section{Policy Conclusions}

There are some important conclusions to be drawn here. In a world economy characterized by globalization and innovation dynamics it is highly relevant to carefully consider the knowledge production function in an open economy and its implications for the macroeconomic production function. As regards the knowledge production function of EU countries, there is clear evidence (JUNGMITTAG/WELFENS, 2016) that the number of researchers, the per capita income and the inward FDI stock relative to GDP significantly raise the number of patent applications. Patents, in turn, raise real GDP so that government's R\&D policy has to consider a complex perspective: It is not only important to ask whether the marginal social domestic benefits exceed private innovators' benefits, rather one should take into account that higher patent applications and actual patents granted, respectively, will also contribute to international real income effects provided that the country considered is big. This international output transmission effect will have a positive real income feedback on the home country - assuming two big countries to be considered (for example the EU and US) - macroeconomic externality. This positive per capita effect - assuming the population in country 1 and country 2 to be given - in turn stimulates R\&D efforts and patent applications, respectively, so that there is a positive intertemporal spillover effect of innovations that so far has not been considered in the 
literature in this context. It might, however, have been covered to some extent indirectly and implicitly in studies looking at path dependency of innovation dynamics. If there are such positive external effects of researchers and inward FDI stocks, there would also be new arguments why government should not only subsidize R\&D activity but inward FDI flows - relative to GDP - as well. A specific question could be to focus on the optimum R\&D activity level (see appendix 1). The impact of globalzation on factor income shares also could be considered in a new way, however, a CES function is adequate for this (some aspects are highlighted in the appendix 2).

The internalization of positive international external effects should guide corporate tax policy, however, there is an international coordination problem since without coordination of tax policy there is the risk of excessive subsidization which could distort factor allocation considerably. In a two country model (with two big countries) there could be a problem of international $R \& D$ policy interaction so that an $R \& D$ subsidy race could occur; if it brings countries closer to the optimum $R \& D$ intensity this should not be considered to be a major problem. Rather, in open economies with rising export-GDP ratios - including exports of the R\&D sector and of innovative intermediate products, respectively - there is some probability that part of $\mathrm{R} \& \mathrm{D}$ efforts will contribute to raising foreign real income so that the problem of low government incentives for an optimum R\&D promotion could increase in the context of economic globlization. In such a context international R\&D cooperation might be required.

The supply-side formulation of the production potential in an open economy with trade, FDI and research is also important for long run output multiplier effects. In an analogy to a Schumpeterian production function for country 1, a similar production function can be stated for country 2, and on this basis the long run equilibrium $\mathrm{Y}, \mathrm{Y}^{*}$ and $\mathrm{Y} \#$ and $\mathrm{Y}^{* \# \text {, }}$ respectively, can be considered. Moreover, the optimum innovation policy at home and abroad can be discussed in a more realistic setup.

Long run as well as medium-term fiscal and monetary policy could be analyzed within the new framework. Generally, one may expect that policymakers will get a much better understanding of the role of innovation dynamics at home and abroad. Some of the important findings of PIKETTY (2014) on changes in income distribution could also be analyzed in a better way (see also WELFENS, 2014; WELFENS, 2015). It also becomes clear that, from a supply-side perspective, globalization - assuming an interplay of both two-way FDI and trade - is not neutral for both small countries and big countries. The Schumpeterian dimension of the macroeconomic production function should be emphasized more clearly and certainly the important role of multinational companies' international investment should become a standard feature of International Macroeconomics. The reflections presented here are both a modest contribution to Schumpeterian Economics and a clear statement in favor of a more realistic open economy macro analysis as well as an approach in favor of taking a broader look at modern regional integration analysis.

Finally, there are crucial implications for the analyis of broad regional integration schemes such as TTIP or TPP and a more realistic and comprehensive empirical analysis. The interaction of trade, foreign direct investment and innovation is crucial to understand in the context of regional integration and integration policies. Moreover, the economic policy debate can be quite misguided if FDI and innovation effects are ignored in deep integration projects (such as TTIP and TPP) - the TTIP-study of FRANCOIS ET AL. (2013) for the 
European Commission that looks mainly at trade effects and to some extent also at FDI aspects while neglecting innovation effects is a typical case. This official study puts the economic welfare effect in the context of trade creation at $0.5 \%$ for the EU and $0.4 \%$ for the US, but this clearly seems to be a considerable underestimation for the two countries ("EU" as a country in an analytical sense) that stand for the two top source countries of international patents and innovation dynamics, respectively, and that also represent the two leading FDI source countries and two of the three global FDI host countries. At the bottom line there are many interesting implications of the new approach presented and much further research will be needed. 


\section{References}

Abdih, Y.; Joutz, F. (2005), Relating the Knowledge Production Function to Total Factor Productivity: An Endogenous Growth Puzzle, IMF Working Paper, WP/05/74.

Aghion, P.; Howitt, P. (1998), Endogenous Growth Theory, Cambridge/Massachusetts: MIT Press.

Asian Development Bank (2015), Asian Economic Integration Report: How Can Special Economic Zones Catalyze Economic Development?, Asian Development Bank, Manila.

Bönte, W. (2001), Wie produktiv sind Investitionen in industrielle Forschung und Entwicklung? (How productive are investments into industrial R\&D), Wirtschaft und Statistik, 2001/4, 312-320.

Coe, D.T.; Helpman, E. (1995), International R\&D Spillovers, European Economic Review, Vol. 39, 859-887.

Dachs, B. (2016), Techno-Globalisierung als Motor des Aufholprozesses im österreichischen Innovationssystem, Beitrag im Rahmen des EIIWForschungsprojektes „EU-Strukturwandel, Leitmärkte und Techno-Globalisierung“, project for Hans-Böckler-Stiftung, Düsseldorf, forthcoming.

Dachs, B. et al. (2014), The Internationalisation of Business R\&D, New Perspectives on the Modern Corporation, Edward Elgar Publishing, Cheltenham, United Kingdom.

Dunning, J.; Lundan, S.M. (2008), Multinational Enterprises and the Global Economy, 2nd edition, Cheltenham: Edward Elgar.

Francois, J. et al. (2013), Reducing Transatlantic Barriers to Trade and Investment, London: CEPR (for the European Commission).

Graham, E.M.; Krugman, P. (1995), Foreign Direct Investment in the United States, 3rd Edition, Peterson Institute Press: All Books, Peterson Institute for International Economics, Washington DC.

Griliches, Z. (1979), Issues in Assessing the Contribution of Research and Development to Productivity Growth," Bell Journal of Economics, vol. 10, 92-116.

Jungmittag, A. (2016), Techno-Globalisierung, Beitrag im Rahmen des Forschungsprojektes „EU-Strukturwandel, Leitmärkte und Techno-Globalisierung“, Hans-Böckler-Stiftung, Düsseldorf, forthcoming.

Jungmittag, A. (2004), Innovations, technological specialization and economic growth in the EU, International Economics and Economic Policy, Vol. 1, 247-273.

Jungmittag, A.; Welfens, P.J.J. (2016), TTIP: Beyond Trade - the Dynamics of Foreign Direct Investment, Patents and Output Growth, EIIW working paper 212, forthcoming.

Jungmittag, A.; Welfens, P.J.J. (2009), Liberalization of EU telecommunications and trade: theory, gravity equation analysis and policy implications, International Economics and Economic Policy, Vol. 6, 23-39. 
Lachenmaier, S.; Wößmann, L. (2006), Does innovation cause exports? Evidence from Exogenous innovation impulses and obstacles using German micro data, Oxford Economic Papers, No. 58, 317-350.

Keller, W. (2000), Geographic Localization of International Technology Diffusion, NBER Working Paper No. 7509, National Bureau of Economic Research.

Machlup, F. (1979), Stocks and Flows of Knowledge, Kyklos, Vol. 32, Issue 1-2, 400-411.

Melitz, M.J. (2003), The Impact of Trade on Intra-Industry Reallocations and Aggregate Industry Productivity, Econometrica, vol. 71, 1695-1725.

Narula, R., Zanfei, A. (2005), Globalisation of Innovation: The Role of Multinational Enterprises, in: Fagerberg, J., Movery, D.C., Nelson R.R. (eds.), The Oxford Handbook of Innovation, Oxford, Oxford University Press, 68-115.

Perret, J.K. (2014), Knowledge as a Driver of Regional Growth in the Russian Federation, Heidelberg and New York: Springer.

Piketty, T. (2014), Capital in the 21st Century, Cambridge, MA.: Belknap Press of Harvard University Press.

Romer, P.M. (1990), Endogenous Technological Change, Journal of Political Economy, Vol. 98, No. 5 (October), pt. II, 71-102.

UNCTAD (1996), World Investment Report 2014: Investing in the SDGs: An Action Plan, United Nations, New York, Geneva.

UNCTAD, 2005, World Investment Report 2005: Transnational Corporations and the Internationalization of R\&D, Geneva.

Veugelers, R. (2005), Internationalisation of R\&D: Trends, Issues and Implications for S\&T policies, Background report for the OECD Forum on the internationalization of R\&D, Brussels.

Welfens, P.J.J. (2015), Innovation, inequality and a golden rule for growth in an economy with Cobb-Douglas function and an R\&D sector, International Economics and Economic Policy, Volume 12, Issue 4, 469-496.

Welfens, P.J.J. (2014), Information \& communication technology and true real GDP: economic analysis and findings for selected countries, International Economics and Economic Policy, Volume 11, Issue 1, 5-27.

Welfens, P.J.J. (2011), Innovations in Macroeconomics, 3rd revised and enlarged edition, Heidelberg and New York: Springer.

World Bank (2016), Global Economic Prospects: Spillovers amid Weak Growth, Washington DC. 


\section{Appendix}

\section{Optimal Choice of the Size of the R\&D Sector}

In the above equation (V) in logs one can replace z'L' by z'L since z'Y= z'L'y (recall that z"Y is the output of the R\&D sector); and z'Y/y = z'L' and z'Y/y= z'L so that z'L=z'L' and hence $\ln \left(z^{\prime} L^{\prime}\right)$ can be replaced by $\ln (z$ 'L). The research share $z$ " in output that maximizes $Y$ thus can be derived (or one maximizes y with respect to $z$ "). Taking the derivative $d \ln Y / d z "$ and setting it equal to zero gives the necessary condition (while assuming: $\left.V^{\prime}+V^{\prime \prime}<1\right)$

$\mathrm{dlnY} / \mathrm{dz} "=\left(-1 /\left(1-\mathrm{z}^{\prime}\right)\right)\left(1 /\left(1-\left(\mathrm{V}^{\prime}+\mathrm{V}^{\prime \prime}\right)(1-\beta)\right)+(1-\beta) \mathrm{V}^{\prime \prime}(1 / \mathrm{z} ") /\left(1-\left(\mathrm{V}^{\prime}+\mathrm{V}^{\prime}\right)(1-\beta)\right)=0\right.$.

$-1 /\left(1-z^{\prime \prime}\right)+(1-\beta) V " / z^{\prime \prime}=0$

$z " /(1-z ")=(1-\beta) V^{\prime \prime}$

For a given V" a graphical solution is possible in V"-z" space.

For a maximum the second derivative should be negative and it is given by the expression

$\mathrm{d}^{2} \ln \mathrm{Y} / \mathrm{dz} \mathrm{z}^{\prime 2}=\left(-1 /\left(1-\mathrm{z}^{\prime \prime}\right)^{2}\right)\left(1 /\left(1-\left(\mathrm{V}^{\prime}+\mathrm{V}^{\prime \prime}\right)(1-\beta)\right)-(1-\beta) \mathrm{V}^{\prime \prime}\left(1 / \mathrm{z}^{\prime \prime}\right) /\left(1-\left(\mathrm{V}^{\prime}+\mathrm{V}^{\prime \prime}\right)(1-\beta)\right)<0\right.$

This equation is fulfilled only for a particular parameter constellation since $V^{\prime}+V^{\prime \prime}<1$ has been assumed here. An alternative approach could be to consider an endogenous growth model based on the Schumpeterian macroeconomic production function and then one considers the steady state situation and maximizes steady state per capita consumption through optimal choice of z". Governments eager to obtain the maximum golden rule consumption per capita will have to consider the profit maximization condition of the $\mathrm{R} \& \mathrm{D}$ sector and on this basis should allocate an adequate subsidy rate to the $\mathrm{R} \& \mathrm{D}$ sector. An extended approach would then additionally include the government budget constraint $G$ $+\mathrm{f}^{\prime} \mathrm{Y}=\tau \mathrm{Y}$ if one assumes that there is no government debt ( $\mathrm{f}^{\prime}$ is the subsidy ratio that should reflect the difference between the social rate of return on innovation and the private rate of return on innovation and $G$ is government consumption - with $G / Y:=\gamma$ to be considered the relevant exogenous variable). This then leads to an optimum tax analysis where $\tau=f^{\prime}+\gamma$.

\section{Schumpeterian CES Function}

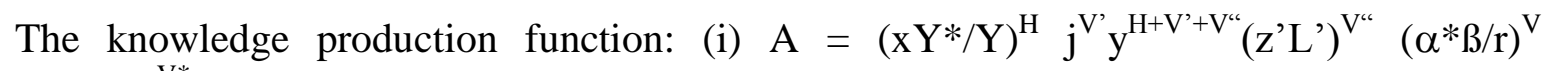
$\left(\alpha \beta^{*} / \mathrm{r}^{*}\right)^{\mathrm{V} *}$

The CES production function - compared to the Cobb Douglas function it is better suitable for analyzing income distribution issues - is given by:

(ii) $\mathrm{Y}=\lambda\left[(1-\Omega)(\mathrm{AL})^{-\mathrm{v} "}+\Omega \mathrm{K}^{-\mathrm{v} "}\right]^{-1 / \mathrm{v}^{\prime \prime}}$

$\left(\Omega>0 ; 0<\Omega<1 ; \infty \geq \mathrm{v}^{\text {“ }} \geq 1 ; \mathrm{v}^{\text {“c }} \neq 0\right.$, elasticity of substitution $\left.\sigma^{\text {“ }}=1 /\left(1+\mathrm{v}^{6}\right) ; \lambda>0\right)$ 
Inserting (i) in (ii) gives

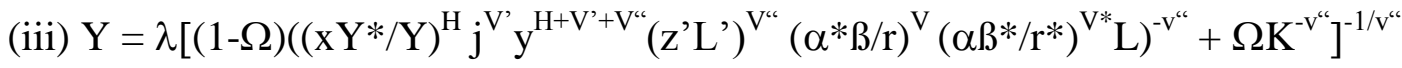

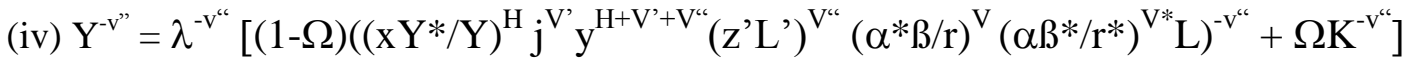

We can solve in a meaningful way for $\mathrm{Y}$ if one assumes that $\mathrm{v}$ " $=\mathrm{V} '+\mathrm{V}$ ':

(iv) $\mathrm{Y}^{-2 \mathrm{v}^{\prime \prime}}=\lambda^{-\mathrm{v}^{\prime \prime}}\left[(1-\Omega)\left(\left(\mathrm{x} \mathrm{Y}^{*}\right)^{\mathrm{H}} \mathrm{j}^{\mathrm{V}^{\prime}}\left(\mathrm{z}^{\prime} \mathrm{L}^{\prime}\right)^{\mathrm{V}^{\mathrm{c}}}\left(\alpha^{*} \beta / \mathrm{r}\right)^{\mathrm{V}}\left(\alpha \beta^{*} / \mathrm{r}^{*}\right)^{\mathrm{V}^{*} \mathrm{~L}}\right)^{-\mathrm{v}^{\mathrm{c}}}+\Omega(\mathrm{K} / \mathrm{Y})^{-\mathrm{v}^{\prime \prime}}\right]$

(iv') $\mathrm{Y}=\lambda^{0.5}\left[(1-\Omega)\left(\left(\mathrm{x} \mathrm{Y}^{*}\right)^{\mathrm{H}} \mathrm{j}^{\mathrm{V}^{\prime}}\left(\mathrm{z}^{\prime} \mathrm{L}^{\prime}\right)^{\mathrm{V}^{\prime \prime}}\left(\alpha^{*} \beta / \mathrm{r}\right)^{\mathrm{V}}\left(\alpha \beta^{*} / \mathrm{r}^{*}\right)^{\mathrm{V}^{*}} \mathrm{~L}^{1-\mathrm{H}-\mathrm{V}^{\prime}-\mathrm{V}^{\prime \prime}}\right)^{-\mathrm{v}^{\prime \prime}}+\Omega(\mathrm{K} / \mathrm{Y})^{-\mathrm{v}^{\prime \prime}}\right]^{-1 / 2 \mathrm{v}^{\mathrm{c}}}$

Dividing (iv) by $\Omega \mathrm{K}^{-\mathrm{v} \text { “ }}$ gives:

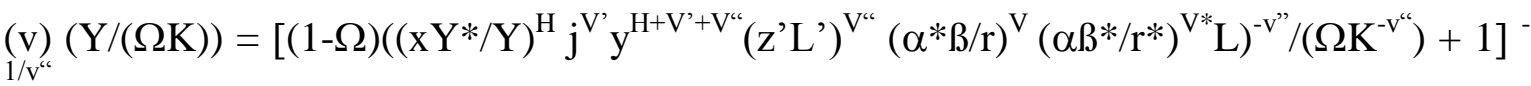

Hence taking logs and using the approxization $\ln \left(1+Z^{\prime}\right) \approx Z^{\prime}-$ for $Z^{\prime}$ close to zero - we can use the approxization:

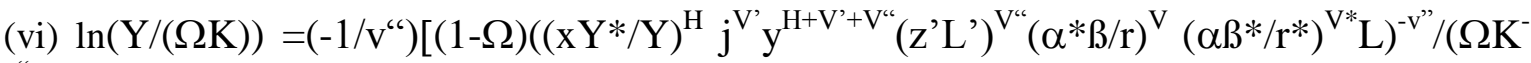
$v^{\text {") })] ~}$ 